\title{
Impact of Tourism Consumption on the Social Development of Host Communities in Cross River State, Nigeria
}

\author{
Anionwu, Carol Ph.D \\ Department of Business Administration, Faculty of Management Sciences, \\ Cross River University Of Technology, Nigeria
}

\section{ABSTRACT}

This study examined the impact of tourism consumption on the social development of host communities in Cross River State, Nigeria. The study is a descriptive survey on a sample of 400 respondents from the host communities. Data obtained for the study were analyzed using descriptive and inferential statistics like the percentages, mean, standard deviation and regression analysis. Findings revealed that tourism consumption has significant social impact on the host communities. The quality of life of the host communities is said to have improved by tourism, thereby leading to an overall improvement in the standard of living of the host communities through the provision of facilities for Tourism purposes. On the negative perspective attitudes such as smoking, drug abuse and crime which are not consistent or in line with morality abide in the studied tourist destination. It was found that the cost of enjoying tourism products and services are relatively high that the poor cannot afford the cost of visiting tourist sites and hotels. Based on the analysis and findings of the study the following recommendations are made: even though it is a difficult task to control the social activities of individuals generally, stakeholder and regulators of tourism in the host communities should make serious efforts to come up with tourism consumption guidelines which should be monitored and enforced. The state government should come up with standard social frameworks that must be established at the development stages to preserve and protect social and cultural values of the host communities.

Keyword: Tourist, Tourism Consumption, Sociological

\section{INTRODUCTION}

In recent time, there is a growing curiosity among researchers and scholars alike on how best to harness the various potentials of tourism for the growth and development of the society. Extant literature (Esu, 2015; Enemuo and Amaechi, 2015; Amissah, 2013; Amissah, 2013; Bac, n.d) asserts that tourism has made tremendous impact in both the developed and emerging economies. Globally, the industry has made economic, social, cultural, and environmental impact on economies that have keyed into the numerous potentials of tourism. Tourism is currently the world's largest industry with annual revenues of over three trillion dollars. It provides over six million jobs in the United States, making it the country's largest employer (Enemuo and Amaechi. 2015; WTO 2004). Apart from being the largest industry and most important export sector in the world, expenditure on tourism has risen fivefold, corresponding to an annual growth rate of about $8 \%$ and it accounts for $12 \%$ of the world's Gross National Product (Amissah, 2013; UNWTO, 2010). According to Bac (undated) tourism generates billions of dollars in revenues and millions of jobs worldwide. It is considered by many communities, especially in emerging countries the only tool for development, and the only chance for increasing their quality of life. Accordingly, Boz and Karakaş (2017) also noted that after fifties, due to changes in economic, sociocultural, and political life such as shorter working weeks, increase in revenues, liberalization of economies and politics, development in infrastructure, and superstructure like new transportation, communication, and accommodation facilities, the middle and lower income level public were able to afford holidays. The number of international tourist arrivals rose from 25 million in 1950 , to 435 million in 1990,675 million in 2000, 942 million in 2010, 1.1 billion in 2013, and 1.14 
billion in 2014 (UNWTO, 2012; UNWTO, 2013; Scowsill, 2015).

The tourism industry in Africa and Nigeria in particular is beginning to attract not only the attention of tourists but also the government, perhaps for the obvious economic benefits accruable to both the government and the host communities. The industry is arguably one of the most important components of the global economy. This is corroborated by Boz and Karakaş (2017) that tourism industry is one of the largest industries in the world and continues to grow regularly. The above benefits and contributions notwithstanding, there is a negative side of tourism particularly the social impact on the host communities. For instance Muhlbauer (2012), argue that tourism could affect social and ecology of a people negatively even when economic gains are recorded. Besides positive impacts of tourism industry, there may be many unforeseeable and hidden economic, social, cultural and environmental costs of tourism development for host communities. It is necessary to carefully study impacts of a rapidly developed tourism industry, because it is possible to make many mistakes in investments and tourism policies in trying to attract tourists (Aydin and Boz, 2006). Development of tourism causes degeneration of moral values, increases the use of alcohol and drugs, causes cultural conflicts, and displaces traditional fashions (Boz \& Karakaş, 2017). In this regard tourism is capable of invading the sociocultural identity of a community. It can also destroy indigenous values, traditions and life style. Consequently, this study becomes imperative as it fills the requisite knowledge and literature gap.

\section{Objective of the Study}

The broad objective of this study is to investigate the impact of tourism consumption on the social development of host communities, particularly in Cross River state, Nigeria.

\section{Research Hypothesis}

$\mathrm{Ho}_{1}$ : Tourism consumption has no significant social impacts on the host communities

\section{Related Empirical Literature}

Liu and Li (2018) examined host perceptions of tourism impact and stage of destination development in a developing country- Puri and Varanasi, India using descriptive statistics and t-test statistics. They collected valid responses from 570 local residents, who displayed a high level of agreement concerning the positive economic and socio-cultural contributions of tourism. Despite environmental concerns, respondents wish to attract more tourists and further develop infrastructure for tourism. Residents who perceive tourism to be in the development and full development/stagnation stages agree more strongly than those who consider tourism to be in the beginning stage that it increases employment opportunities and seasonality and stipulates cultural activities. In contrast, those who think tourism is in the beginning stage are more concerned about environmental pollution and thus advocate restrictions on the industry. Boz and Karakaş (2017) examined the impact of tourism industry on host communities: Antalya and Canakkale cases using a quantitative research technique. The study revealed that there are significant differences between perception and attitudes of local people who live in Antalya and Canakkale. The development of tourism increases the desire of people to learn a foreign language and to become acquainted with foreign cultures. Tourism improves social life of host communities, and contributes women in participating to labour force. The tourism industry provides a positive contribution to the solution of unemployment problem. Kalantzi, Tsiotas and Polyzos (2016) examined the contribution of tourism in national economies: evidence of Greece using descriptive and inferential statistic like tables, charts, t-test statistics and Pearson's bivariate correlations. At the period, the available data (20002012) two events of the recent Greek history are distinguished as the most significant (the Olympic Games in the year 2004 and the economic crisis initiated in the year 2009) and their impact on the diachronic evolution in tourism is discussed. Findings revealed that under an overall assessment, the analysis illustrated that tourism is a sector of the Greek economy, which is described by a significant resilience. However, it seems that it has not yet been submitted to an effective developmental plan exploiting the endogenous tourism dynamics of the country. This suggests currently a promising investment of "low risk" for the economic growth of country and the exit of the economic crisis. Enemuo and Amaechi (2015) examined the role of mass media in tourism development in Abia State using descriptive statistics. Findings from the study revealed that National War Museum at Umuahia was the most visited tourism destination in Abia State with 56.8\% of all the interviewed tourists having visited it. Wonder tree in Amakama was the second most visited 
destination. Yusuff and Akinde (2015) investigated tourism development and economic growth nexus: Nigeria's experience using the VECM regression method and data spanning from 1995 to 2013. The findings reveal a unilateral causality and positive long-run between tourism development and economic growth. The tourism-led growth is also thus confirmed for Nigeria. Zaei and Zaei (2013) analsyed the impacts of tourism industry on host communities. They posit that tourism is one of the dynamic economic activities in creating socio - economic changes across the world which has been increasingly important. The tourism sector is probably the only service sector that provides concrete and quantified trading opportunities for all nations, regardless of their level of development. However, it is also a sector where there is clearly an uneven distribution of benefits, which is threatening the social, economic and environmental sustainability of tourism in some developing countries. For many developing countries, tourism is one of fundamental pillars of their development process because it is one of the dominant activities in the economy, while for others, particularly by islands and some small economies, it is the only source of foreign currency and employment, and therefore constitutes the platform for their economic development. Amissah (2013) investigated tourist satisfaction with hotel services in Cape Coast and Elmina, Ghana using the gap model. The results revealed four main factors which influence tourists' satisfaction with hotel services. Also, there was a significant relationship between satisfaction and revisit intentions. Enemuo and Oduntan (2012) investigated the social impact of tourism development on host communities of Osun Oshogbo Sacred Grove. Simple frequency percentages, mean and Analysis of variance (ANOVA) derived from regression analysis were used to analyse the data generated for the study. The findings of the analysis proved that tourism development had significant effect on the social lives of the host communities and tourism development had significant effect on the sustainability of the sociocultural lives of the host communities. Ogbu, Idris and Ijagbemi (2011) examined information and communication technology (ICT): A veritable tool for tourism development in Nigeria using descriptive statistics and secondary data from UNWTO technical manual of various issues. Findings revealed that almost every tourism products can be sold online without the consumer necessarily visiting the place before making any choices. Booking of flights and hotel reservations can be done online through e-mail, telephone calls and other internet services thereby helping to reduce if not remove entirely the time wasting processes of the old system. Spanou (2010) examined the impact of tourism on the socio-cultural structure of Cyprus using descriptive statistics. The study revealed that in spite of all the negative and positive impacts of tourism on Cyprus it is not yet clear whether the benefits outweigh the costs. The reason for this uncertainty is that most of the research is done on an estimate as there is no empirical data available as yet to support either side of the equation. However, it also revealed that the residents of Cyprus have a positive attitude toward tourism. Since the success of tourism depends very much on the human factor, i.e. the attitudes and behaviour of the residents of a destination towards tourists, this seems to be an encouraging result for the future of tourism development. Residents recognize a range of potential positive and negative impacts of tourism. However, current attitudes are generally quite positive and there is support for future modest increase in tourism.

The findings from various researches have shown that there is a mixed impact of tourism consumption on host communities in different regions and countries across the globe. It is however not clear whether tourism consumption has had a higher positive or negative impact on the host communities in Nigeria. Also, there is paucity of literature in this area of growing intellectual curiosity of tourism development in Nigeria. This study therefore fills the gap by examining the impact of tourism consumption on the social development of host communities, particularly in Cross River State, Nigeria.

\section{METHODOLOGY}

\section{Research Design}

This study adopts a descriptive survey research design. Descriptive survey research design can be quantitative or qualitative, but this study is quantitative in nature. According to Micheal, Oparaku and Oparaku (2012), in a quantitative survey research design, the researcher's aim is to determine the relationship between the independent variables and dependent variable in a population. Quantitative research design is either descriptive (variables usually measured once) or experimental (variables measured before and after a treatment). The questions asked are to elicit responses that will answer the research questions and address the objectives of the research. 


\section{Population of the Study}

The unit of analysis/defined population for the study is made up all individuals that constitute host communities who themselves may be also the stakeholders. They are also the beneficiaries (positive or negative) of the outcome of Tourism consumption activities for this study the unit of analysis of this study is finite. In the present study the population are drawn from three tourist zones (Calabar Municipal local Government Area, Obudu Local Government Area and Odukpani Local Government Area) in Cross River state. According to the National Population Commission of Nigeria the populations of the catchment areas are: Odukpani LGA: 179,392, Obudu LGA: 186,650 and Calabar: 222,980 respectively. The population is finite (that is it is known) because the researcher was able to obtain the estimate of the total population of the catchment areas for the study which come to 589,022 .

Table 1: Host Communities

\begin{tabular}{|c|c|c|}
\hline $\begin{array}{c}\text { Name of } \\
\text { Societies }\end{array}$ & $\begin{array}{c}\text { Population of the } \\
\text { Host Communities }\end{array}$ & $\begin{array}{c}\text { Sample } \\
\text { Size }\end{array}$ \\
\hline Odukpani LGA & 179,392 & 122 \\
\hline Obudu LGA & 186,650 & 127 \\
\hline Calabar LGA & 222,980 & 151 \\
\hline Total & 589,022 & $\mathbf{4 0 0}$ \\
\hline
\end{tabular}

Source: computation from field survey, 2016. questionnaire distribution; the Taro Yamani formula was used.

The formula is stated as thus: $\mathrm{n}=$

$$
\begin{array}{ll}
\text { Where: } & =\text { Sample size } \\
\mathrm{N} & =\text { Population } \\
\mathrm{E} & =\text { Margin error }(5 \% \text { or } 0.05) \\
\mathrm{I} & =\text { Constant }
\end{array}
$$

To determine the sample size, for the purpose of

$\mathrm{nh}=\underline{\mathrm{nNh}}$

Where $\mathrm{n}=\mathrm{N}$ Total sample size
$\mathrm{Nh} \quad=$ The number of items in each
$\mathrm{N} \quad=$ stratum in the population
$\mathrm{nh} \quad=$ The number of units allocated

to each stratum

$$
\mathrm{n}=400
$$

Substituting in the above formula for the purpose of allocating the questionnaire to the host communities, we have:

Odukpani; $=>\mathrm{nh}=\underline{400 \times 179,392}=121.8$ $=122$

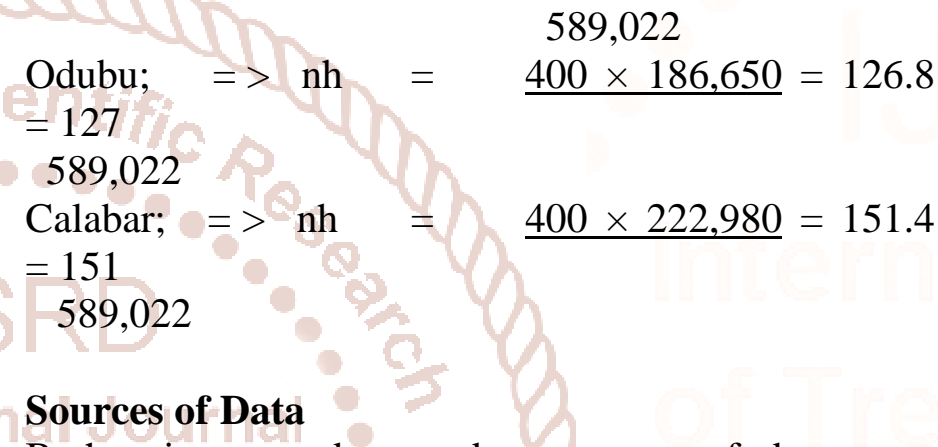

Both primary and secondary sources of data were employed by the researcher for this study. Secondary sources were made up of published works by other authors closely related to the present topic, they include: books, professional journals, business and government reports. Primary data were generated from the field through the use of structured questionnaires.

\section{Research Instrument}

The major instrument used for this study was the questionnaires which were constructed to tap information from the respondents. The 5 point summative scale the rating scale model questionnaire was adopted. The rating scale is shown as follows;

Substituting in the above formula:

$$
\begin{aligned}
\mathrm{N} & =\underline{589,022} \\
& =\underline{1+589,022(0.05)^{2}} \\
& 1+58 \underline{589,022} \\
& =\frac{5822(0.0025)^{2}}{} \\
& =399.022 \\
\simeq \quad 400 &
\end{aligned}
$$

For the purpose of allocation of sample stratum, the researcher adopted R. Kumaisons (1997) formula. Below is the R. Kumaisons formula for sample size distribution:

\section{Table 1: 5 Point Summative Rating Scale Model}

\begin{tabular}{|c|c|c|c|c|}
\hline $\mathbf{0}$ & $\mathbf{1}$ & $\mathbf{2}$ & $\mathbf{3}$ & $\mathbf{4}$ \\
\hline $\begin{array}{c}\text { No } \\
\text { impact } \\
\text { at all }\end{array}$ & $\begin{array}{c}\text { Low } \\
\text { impact }\end{array}$ & $\begin{array}{c}\text { Moderate } \\
\text { impact }\end{array}$ & $\begin{array}{c}\text { High } \\
\text { impact }\end{array}$ & $\begin{array}{c}\text { Very } \\
\text { high } \\
\text { impact }\end{array}$ \\
\hline
\end{tabular}

The questionnaires were designed based on previous empirical studies carried out by researchers on the economic and socio-ecological impact of tourism. Additionally, the preceding researcher adopted some questionnaire items from Brunt and Courtney (1999), Ribeiro, Vareiro, and Remoaldo (2012) in their socio- 
International Journal of Trend in Scientific Research and Development (IJTSRD) ISSN: 2456-6470

economic and environmental (SEE) impacts as well as tourist-host interaction studies respectively.

\section{Method of Data Analysis}

The study is concerned with finding the impact of an independent variable (e.g. Tourism, which is deconstructed with sub-variables such as Service, Products, Hotel, Transportation, and Infrastructural Facilities) on 3 dependent variables (e.g. Economic Well-Being, Ecological Development and Sociological Development). Consequently, the researcher used the Regression Analysis of ordinary least square.

\section{Model Specification}

The structural form of the model

$\mathrm{SOI}=\mathrm{f}(\mathrm{SER}, \mathrm{PRO}, \mathrm{HOT}, \mathrm{TRAN}, \mathrm{INF}) \ldots(1)$

The mathematical form of the model

$\mathrm{SOI}=\beta_{0}+\beta_{1} \mathrm{SER}+\beta_{2} \mathrm{PRO}+\beta_{3} \mathrm{HOT}+\beta_{4} \mathrm{TRAN}+\beta_{5}$

INF

The econometric form of the model

$\mathrm{SOI}=\beta_{0}+\beta_{1} \mathrm{SER}+\beta_{2} \mathrm{PRO}+\beta_{3} \mathrm{HOT}+\beta_{4} \mathrm{TRAN}+\beta_{5}$

$$
\mathrm{INF}+\mu_{\mathrm{i}}
$$

Where;

SOD $=$ SOCIAL DEVELOPMENT

SER = SERVICE

PRO $=$ PRODUCTS

HOT $=$ HOTELS

TRA $=$ TRANSPORTATION

INF $=$ INFRASTRUCTURAL FACILITIES

$\mathrm{f}=$ Functional relationship

$\beta_{0}=$ the intercept or the constant

$\beta_{1}-\beta_{5}=$ the co-efficient of the explanatory variables

$\mu_{\mathrm{t}}=$ Stochastic error term.
Table 2: Economic a priori expectation

\begin{tabular}{|c|c|c|c|c|}
\hline \multirow[b]{2}{*}{$\begin{array}{c}\text { Parame } \\
\text { ters }\end{array}$} & \multicolumn{2}{|c|}{ Variables } & \multirow[b]{2}{*}{$\begin{array}{c}\text { Expected } \\
\text { Relations } \\
\text { hips }\end{array}$} & \multirow{2}{*}{$\begin{array}{c}\text { Expecte } \\
\text { d } \\
\text { Coeffici } \\
\text { ents }\end{array}$} \\
\hline & $\begin{array}{c}\text { Regr } \\
\text { ess } \\
\text { and }\end{array}$ & $\begin{array}{l}\text { Regre } \\
\text { ss or }\end{array}$ & & \\
\hline$\beta_{0}$ & SOI & $\begin{array}{c}\text { Interc } \\
\text { ept }\end{array}$ & $(+/-)$ & $\begin{array}{c}0<\beta_{0}> \\
0\end{array}$ \\
\hline$\beta_{1}$ & SOI & SER & + & $\beta_{1}<0$ \\
\hline$\beta_{2}$ & SOI & PRO & + & $\beta_{2}<0$ \\
\hline$\beta_{3}$ & SOI & HOT & + & $\mathrm{B}_{3}<0$ \\
\hline$\beta_{4}$ & SOI & TRA & + & $\beta_{4}<0$ \\
\hline$\beta_{5}$ & SOI & INF & + & $\beta_{5}<0$ \\
\hline
\end{tabular}

Source: Researchers compilation

A positive ' + ' sign indicate that the relationship between the regress or and regress and is direct and move in the same direction i.e. increase or decrease together. On the other hand, a '-' shows that there is an indirect (inverse) relationship between the regress or and regress and i.e. they move in opposite or different direction.

\section{DATA PRESENTATION AND ANALYSIS} Administration and Collection of Instrument

The total number of questionnaire distributed was 400. This was determined by the sample size of the study. The number returned was a total of 300copies, representing $75 \%$ (percent) of number distributed. This shows that the number not returned was 100 $(25 \%)$. Based the above, the return rate is considered sufficiently high. This is in consonance with $70 \%$ return rate benchmark suggested by some researchers for example Kathari, (2011).

\section{Data Presentation}

This data presentation section is divided into two subsections. The first subsection deals with demographic profile of the respondents. The second subsection deals with the presentation of responses on core subject matter.

\section{Demographic Profile of Respondents}

Table 3 gives an overview of the demographic and socioeconomic characteristics of the sample.

Table 3: Demographic profile of the sample

\begin{tabular}{|c|c|c|c|}
\hline Demographic profile & Frequency & Percentage (\%) & Cumulative Percent \\
\hline Sex/Gender & \multicolumn{3}{|l|}{} \\
\hline Male & 180 & 60.0 & 60.0 \\
\hline Female & 120 & 40.0 & 100.0 \\
\hline Age & \multicolumn{3}{|l|}{} \\
\hline $18-25$ & 164 & 54.7 & 54.7 \\
\hline $26-35$ & 80 & 26.7 & 81.3 \\
\hline $36-60$ & 56 & 18.7 & 100.0 \\
\hline
\end{tabular}


International Journal of Trend in Scientific Research and Development (IJTSRD) ISSN: 2456-6470

\begin{tabular}{|c|c|c|c|}
\hline Marital Status & & & \\
\hline Single & 182 & 60.7 & 60.7 \\
\hline Married & 118 & 39.3 & 100.0 \\
\hline \multicolumn{4}{|l|}{ Occupation } \\
\hline Civil Servant & 38 & 12.7 & 12.7 \\
\hline Lecturer & 19 & 6.3 & 19.0 \\
\hline Business/Trading & 45 & 15.0 & 34.0 \\
\hline Others & 198 & 66.0 & 100.0 \\
\hline \multicolumn{4}{|l|}{ Place of work } \\
\hline Hotel and Tourism & 20 & 6.7 & 6.7 \\
\hline Others & 280 & 93.3 & 100.0 \\
\hline \multicolumn{4}{|l|}{ Annual income } \\
\hline$\$ 1,000-\$ 199,000$ & 207 & 69.0 & 69.0 \\
\hline$\$ 200,000-\$ 500,000$ & 71 & 23.7 & 92.7 \\
\hline$\$ 600,000-\$ 1,000,000$ & 12 & 4.0 & 96.7 \\
\hline$\$ 1,100,000-\$ 2,000,000$ & 10 & 3.3 & 100.0 \\
\hline Educational Qualification & A1: $=$ & $-4 / / \mathrm{C}$ & \\
\hline OND/WASC & 244 & 81.3 & 81.3 \\
\hline PGD/First Degree/ HND & 16 & 5.3 & 86.7 \\
\hline Masters Degree & 22 & 7.3 & 94.0 \\
\hline $\mathrm{PhD}$ & 18 & 6.0 & 100.0 \\
\hline
\end{tabular}

\section{Source: Field Survey 2016}

From table $4.1,60.0 \%$ of males responded to the questionnaire while $40.0 \%$ of the respondents are females. Majority of the respondents, that is $54.7 \%$, are between the ages of 18-25 years. $26.7 \%$ of them fall between the age's 26-35years, while $18.7 \%$ of the respondents are between the ages of 36-60years. The marital status of the respondents revealed that $60.7 \%$ of the respondents are single, while $39.3 \%$ of the respondents are married.

The same table shows that over $12.7 \%$ of the respondents are civil servants, while $6.3 \%$ of them are lecturers, $15.0 \%$ of the respondents are into business/trading, $66.0 \%$ of the respondents are into other forms of businesses. Annual income revealed that $69.0 \%$ of the respondents earn between $\$ 100$, 000 - N 199000, 23.7\% earn between $\$ 200000$ $\$ 500000$. $4.0 \%$ of the respondents earn between $\$ 600000$ - $\$ 1000000$ per annum and 3.3\% earn between $\$ 1100000$ - $\$ 2000000$ per annum.

The above figures show that majority of the members of the Host Communities (almost 70\%) are low income earners or otherwise referred to the bottom-ofthe-pyramid earners. This therefore is the more reason it has become imperative to find out what improvement has come to them through Tourism. Table 2 also indicates that all the respondents had formal education. Majority of the respondents $81.3 \%$ had West African School Certificate (WASC)/ Ordinary National Diploma (OND). Only 5.3\% had FIRST DEGREE/Higher National Diploma (HND)/ Post Graduate Diploma (PGD). Finally, 7.3\% had Masters Degree while 6.0\% had Ph.D. Given these statistics, the researcher was delighted to note that a good majority of the respondents had what can be described as acceptable formal educational background which was a plus for the Host Communities. It made it reassuring and made it possible for them to attend to the questions with ease. And indeed they reacted intelligently and satisfactorily to the questionnaire. This was an evidence which showed that they are very much aware and alive to their environment. 
International Journal of Trend in Scientific Research and Development (IJTSRD) ISSN: 2456-6470

\section{Regression Result}

Table 4: the extent to which Tourism Consumption (TC) affects the Social Development of the Host Communities

\begin{tabular}{|c|c|c|c|c|}
\hline Model & B & Std. error & T & Sig. \\
\hline (Constant) & -.162 & .043 & -3.071 & 0.003 \\
\hline IMPACT OF PRODUCTS & .172 & .040 & -0.311 & 0.757 \\
\hline IMPACT OF SERVICES & .276 & .054 & -4.325 & 0.000 \\
\hline IMPACT OF HOTELS & .210 & .068 & 9.282 & 0.000 \\
\hline IMPACT OF TRANSPORTATION & .032 & .052 & 4.208 & 0.000 \\
\hline IMPACT OF INFRASTRUCTURE & .378 & .064 & -1.969 & 0.052 \\
\hline $\mathrm{R}$ & 0.976 & & & \\
\hline $\mathrm{R}^{2}$ & 0.952 & & & \\
\hline Adj. $\mathrm{R}^{2}$ & 0.951 & & & \\
\hline F-statistic & 1157.201 & & & 0.000 \\
\hline
\end{tabular}

\section{Source: Field Survey 2016}

Dependent Variable: SOCIAL DEVELOPMENT

Table 4 shows the regression results of the impact of tourism consumption on the social development of the host communities. This was analysed using economic a priori criteria and statistical criteria.

Using the economic a priori criteria (i.e., theoretical) expectations, the sign and magnitude of each variable coefficient is evaluated against theoretical expectations. From table 4 , it is observed that the regression line has a negative intercept as presented by the constant $(\mathrm{c})=-.162$. This means that if all the variables are held constant or fixed (zero), the social development of the host communities will be valued at -.162. Thus, the a-priori expectation is that the intercept could be positive or negative, so it conforms to the theoretical expectation. It is observed in Table 4 that product, services, hotels, transportation and infrastructure have positive impact on the social development of the host communities. This means that if product, services, hotels, transportation and infrastructure are developed and improved, it will bring about more increase in the social development of the host communities.

Here the $\mathrm{R}^{2}$, adjusted $\mathrm{R}^{2}$ and the $\mathrm{f}$-test are used to determine the statistical reliability of the estimated parameters. These tests are performed as follows: From our regression result, the coefficient of determination $\left(\mathrm{R}^{2}\right)$ is given as 0.952 , which shows that the explanatory power of the variables is extremely high and/or strong. This implies that $95.2 \%$ of the variations in the social development of the host communities are being accounted for or explained by the variations in the development of product, tourism, hotels, transportation and infrastructure in the host communities. While other independent variables not captured in the model explain just $4.8 \%$ of the variations in the social development of the host communities.

The adjusted $\mathrm{R}^{2}$ supports the claim of the $\mathrm{R}^{2}$ with a value of 0.951 indicating that $95.1 \%$ of the total variation / in the dependent variable (social development of the host communities is explained by the independent variables (the regressors)). Thus, this supports the statement that the explanatory power of the variables that is extremely high and strong.

\section{Test of Hypothesis}

Ho: Tourism consumption has no significant social impact on the host communities.

Table 5: Impact of Tourism Consumption on the social development of the Host Communities

\begin{tabular}{|c|c|c|c|c|c|}
\hline Model & $\begin{array}{c}\text { Sum of } \\
\text { Square } \\
\mathrm{s}\end{array}$ & $\begin{array}{c}\text { Mean } \\
\text { Squar } \\
\mathrm{e}\end{array}$ & $\mathrm{F}$ & Sig. \\
\hline $\begin{array}{c}\text { Regressio } \\
\mathrm{n}\end{array}$ & $\begin{array}{c}414 . \\
571\end{array}$ & 5 & $\begin{array}{c}82.91 \\
4\end{array}$ & $\begin{array}{c}1157 \\
.201\end{array}$ & $\begin{array}{c}.000 \\
\mathrm{~b}\end{array}$ \\
\hline Residual & 21.065 & 29 & .072 & & \\
\hline Total & $\begin{array}{c}435 . \\
637\end{array}$ & $\begin{array}{c}29 \\
9\end{array}$ & & & \\
\hline
\end{tabular}


The F-statistic: The F-test is applied to check the overall significance of the model. The F-statistic is instrumental in verifying the overall significance of an estimated model. In our model the F-statistic is significant at 0.000

We therefore reject $\mathrm{H}_{0}$ and accept $\mathrm{H}_{1}$ that the model has goodness of fit and is statistically significant. In other words, tourism consumption has significant social impact on the host communities.

\section{Conclusion}

There is a cumulative link between Tourism Consumption and Social development of the society and Host Communities in particular. These constructs were used to measure the impact of Tourism Consumption in the zones. The objective of the study was raised to address the issue of Sociological Impact of Tourism Consumption on Host Communities of Cross River State. The findings present two perspectives while addressing sociological aspects of Tourism - the Good and the Bad. But along with these aspects, the perception of the Host Communities indicates that there are a number of positive impacts. These include the eradication of certain primitive and traditional beliefs and myths, for example, female genital mutilation, human sacrifices and other repugnant ancestral practices were put to rest. Furthermore, tourism according to the findings has brought money to economically depressed enclaves of the Host Communities. The quality of life of the host communities is said to have improved by tourism, thereby leading to an overall improvement in the standard of living of the host communities through the provision of facilities for Tourism purposes.

The implication of all of these is that tourism alters the internal structure of the Host Communities into those who have and those who have not. Thus, tourism provides not just social but socio-economic benefits for the host communities. Nevertheless, with the influx of tourists to a tourism destination, people or rather the host communities are exposed to the value of education as they interact among each other Host Communities - Tourists.

On the negative perspective, attitudes such as smoking, drug abuse and crime which are not consistent or in line with morality abide in the studied tourist destination. Moreover, there exists the tendency of the host communities to contact disease from tourists. Also, due to the inadequate carrying capacity of the studied tourist sites, tourism exposes residents in host communities to stress caused by congestions. Furthermore, it was found that the cost of enjoying tourism products and services are relatively high that the poor cannot afford the cost of visiting tourist sites and hotels. This invariably points to the fact that only the rich have the opportunity to enjoy their money while the poor people have nothing to gain from tourism.

\section{Recommendations}

Based on the analysis and findings of the study the following recommendations are made:

Even though it is a difficult task to control the social activities of individuals generally, stakeholder and regulators of tourism in the host communities should make serious efforts to come up with tourism consumption guide lines which should be monitored and enforced. The state government should come up with standard social frameworks that must be established at the development stages to preserve and protect social and cultural values of the host communities.

\section{References}

1. Amissah, E. F. (2013). Tourist Satisfaction with Hotel Services in Cape Coast and Elmina, Ghana. American Journal of Tourism Management, 2(1A), 26-33.

2. Boz, M. \& Karakaş, E. (2017). Impact of tourism industry on host communities: Antalya and Canakkale cases. Researcher: Social Science Studies, 5(8), 153-170.

3. Enemuo, O. B. \& Amaechi, B. (2015). The Role of Mass Media in Tourism Development in Abia State. Journal of Tourism, Hospitality and Sports, 11: 44-49.

4. Enemuo, O. B. \& Oduntan, O. C. (2012). Social Impact Of Tourism Development On Host Communities Of Osun Oshogbo Sacred Grove. Journal of Humanities and Social Science, 2(6), 30-35.

5. Esu, B. B (2015). Transforming the Nigeria tourism industry through tourism entrepreneurial development. African Journal of Business Management. 9(15), 569 - 580.

6. Kalantzi, O., Tsiotas, D. \& Polyzos, S. (2016). The contribution of tourism in national economies: evidence of Greece. European Journal of Business and Social Sciences, 5(5), 41 - 64. 
7. Liu, X. \& Li, J. (2018). Host perceptions of tourism impact and stage of destination development in a developing country. Sustainability, 10: 1-15.

8. Ogbu, S. E., Idris, S. \& Ijagbemi, A.B. (2011). Information and communication technology (ICT): A veritable tool for tourism development in Nigeria. A paper presented at Nigeria Computer Society (NCS): 10TH International Conference July 25-29, 2011.

9. Spanou, E. (2010). The impact of tourism on the sociocultural structure of Cyprus. An International Multidisciplinary Journal of Tourism, 2(1), 145162.
10. UNWTO (2010) Tourism Highlight, 2010 Edition, p. 3. Vavra, T.G. (1997) "Improving Your Measurement of Customer Satisfaction: A Guide to Creating, Conducting, Analyzing and Reporting Customer Satisfaction Measurement Programs, ASQ Quality Press.

11. Yusuff, M. A. and Akinde, M. A (2015). Tourism development and economic growth nexus: Nigeria's experience. European Journal of Hospitality and Tourism Research, 3(4), 1-10.

12. Zaei, M. E. \& Zaei, M. E. (2013). The impacts of tourism industry on host community. European Journal of Tourism Hospitality and Research, $1(2), 12-21$. 